\title{
INFLUENCE OF PHYSICAL FACTORS ON PASTURE GROWTH ON HILL COUNTRY
}

\author{
A. G. GiLlingham \\ Ruakura Agricultural Research Centre, Hamilton
}

\section{Abstract}

Pasture on north aspects of steep hill country (Waingaro steepland soil) produced more dry matter than on south aspects (7100 $\mathrm{kg} / \mathrm{ha}$ cf. $6400 \mathrm{~kg} / \mathrm{ha}$ ) owing predominantly to a significantly higher growth rate during winter and early spring. Pasture species composition differed between aspects and changed during the year, especially on north aspects where Paspalum dilatatum and pasture dead matter content varied inversely with the amount of legumes and other grasses.

A highly significant negative relationship between land slope and production accounted for $22 \%$ of the variability in pasture growth rate on both north and south aspects over the major part of the year excluding late autumn and winter. Soil moisture and grass temperature differed with aspect and also in their individual effect on pasture growth during the year.

Temperature level and difference between aspects was found to be affected to a large extent by cloud cover, especially during winter on the south aspect (warmer than in clear weather) and during summer on the north aspect (cooler than in clear weather).

\section{INTRODUCTION}

A MAJOR FACTOR causing variability in pasture growth rate and species composition is the fertility of the soil. On hills this effect is further complicated by changes in slope and aspect of the soil surface. On moderately steep hill country, variable pasture utilization and nutrient return by the grazing animal can cause marked differentiation within a paddock (Gillingham and During, 1973) and where the slope is steep enough to develop stock tracks these add further to soil and pasture variability (During and Radcliffe, 1962; Rumba11 and Esler, 1968). The most distinguishing feature of hill country is the sloping nature of the soil surface and this report covers an initial evaluation of the influence of steepness and direction of slope on soil moisture and temperature, and on pasture production during the year.

The trial 'area was at Whatawhata Hill Country Research Station (latitude 37' 48') and consisted of separate paddocks 
on north and south aspects of steep (mean 30" slope) hill country, with seven-year-old pasture originally developed from bracken. The soil on the slopes was Waingaro steepland, a yellowbrown earth derived from argillite and argillaceous greywacke. Available soil phosphate and potassium levels were moderate but $\mathrm{pH}$ was low (4.8 mean). The area was annually topdressed with $375 \mathrm{~kg}$ superphosphate/ha and rotationally grazed by Romney ewes and hoggets as required.

For three years measurements were made on three faces within each 'aspect and confined to slope or inter-track areas. Such areas occupied the major proportion of the ground surface and were considered subject to the greatest effect by slope and aspect on plant growth.

Soil moisture was measured gravimetrically from two fixed sites on each face (6 per aspect) initially at weekly, and, after the first year, at fortnightly intervals. One Grant recording thermograph per aspect was used to measure grass temperatures under selected clear sky (direct radiation), and full cloud (diffuse radiation) conditions in each month of the final year of the trial. Mean daily temperatures were estimated only from values above 5.5" C since this was selected as the threshold level for grass growth (McCloud et al., 1964).

Thirty-six small $\left(5.6 \mathrm{~m}^{2}\right.$ area) plots were randomly located over the three separate faces on each aspect and pasture dry matter production was measured by the trim technique from a $0.18 \mathrm{~m}^{2}$ cage rotated around each plot. All but the caged 'area was open to grazing at any time and the slope of each cage position was recorded. Pasture was cut to a height of about $1 \mathrm{~cm}$ at intervals of 4 to 8 weeks depending on pasture growth. In autumn the interval was longer if dry conditions persisted. Dissection of pasture samples provided information on their species composition.

\section{RESULTS}

\section{Soll Moisture}

The moisture level of topsoil $(0$ to $7.5 \mathrm{~cm})$ on the south aspect exceeded that of the north at all times of the year (Fig. 1).

The pattern of change in soil moisture level during the year was similiar on both aspects; at a maximum near field capacity (north $35.1 \%$ by volume; south $47.8 \%$ by volume) from June to October and then a rapid fall to a minimum in January and February. North aspect moisture level was below wilting point 


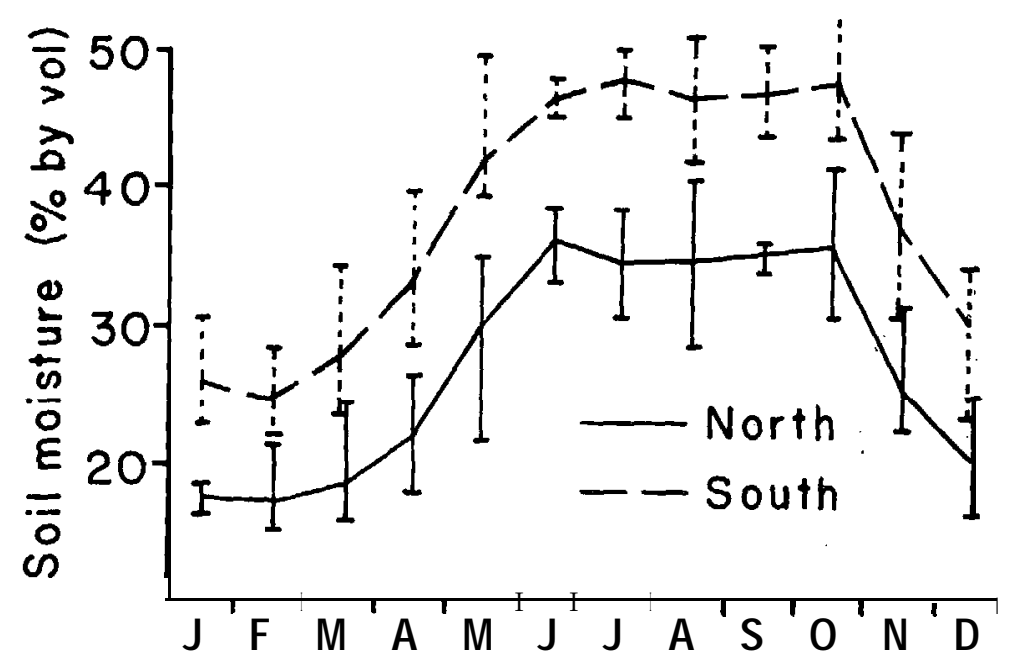

FIG. 1: Mean monthly soil moisture confent ( $\%$ by volume) and range in mean monthly values from August 1970 to July 1973.

( $19.9 \%$ by volume) from January to March and only briefly replenished by any rain during this period. South aspect average monthly value, on the other hand, did not fall to wilting point (22.0\% by volume) although from December 1970 to March 1971 levels below this threshold were measured. The difference between aspects was least during late summer but increased during autumn as the south soil rewet more rapidly than the north until the respective field capacity levels were reached in early winter.

Subsoil $(7.5$ to $15.0 \mathrm{~cm})$ moisture content was higher than in topsoil during late summer and 'autumn but in winter and spring the situation was reversed.

\section{Grass Temperature}

The iemperature recording system revealed some marked effects of aspect and cloud cover. However, although it was designed to short-cut the need for collection of long-term records, results did suffer from the limitations of only one year's data and were 'affected by atypically cool, cloudy weather in both August and December 1972. At all times of the year, the daily mean grass temperature on north aspects was greater than on south facing slopes (Fig. 2). This was due to the higher day 
temperatures on the north than on the south since the grass minimum temperatures on both areas were always similar.

At most times of the year the greatest difference between aspects was during clear weather - i.e., under direct radiation. This was particularly so both in winter, owing to very low temperatures on the south aspect, and also in summer when the north slopes were very warm. Grass temperatures during cloudy weather were much less extreme.

\section{Pasture Species Composition}

The composition of the pasture varied with season and differed between aspects. Samples collected from winter 1972 to 'autumn 1973 illustrate this variability (Fig. 3) . The most notable difference between aspects was that Paspalum dilatatum was the dominant species on the north in summer (19\%) and autumn (27\%) but was entirely absent from the south at all times.

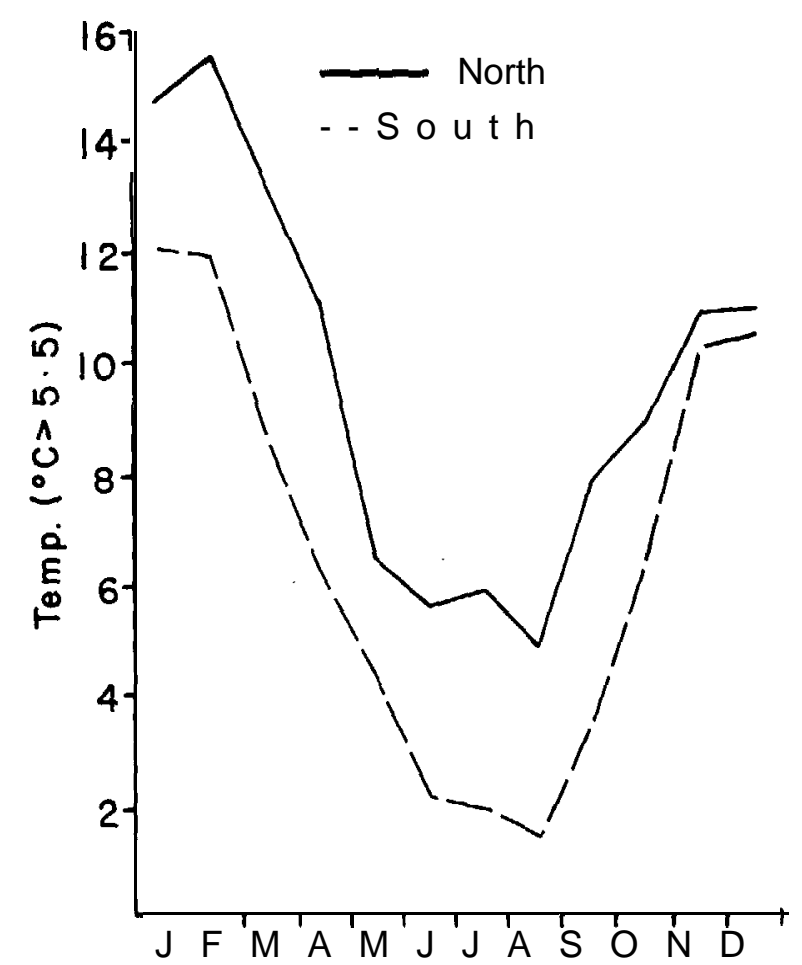

FIG. 2: Daily mean grass temperature ( ${ }^{\circ} \mathrm{C}$ greater than 5.5) May 1972 to May 1973. 

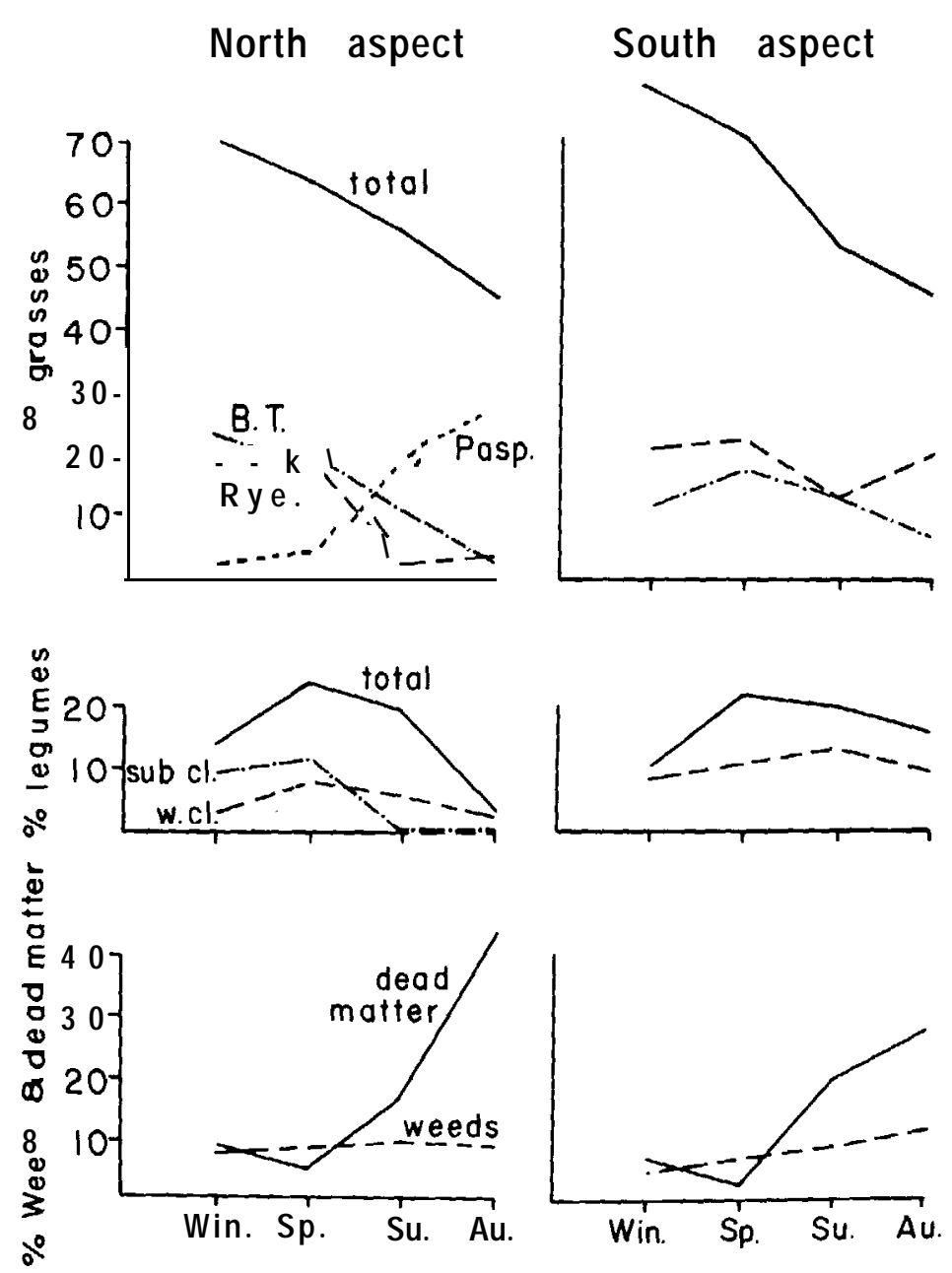

FIG. 3: Pasture species composition ( $\%$ by weight).

Perennial ryegrass (Lolium perenne) and browntop (Agrostis tenuis) were prominent on both aspects in winter and spring. These fell to a very low level on the north aspect in summer and autumn, but on the south remained relatively abundant, particularly ryegrass.

Ten other grasses were present in the sward during the year (cocksfoot (Dactylis glomerata) ; crested dogstail (Cynosurus cristatus); annual meadow grass (Poa annua); sweet vernal 
(Anthoxanthum odoratum) ; ratstail (Sporobolus africanus) ; Yorkshire fog (Holcus lanatus); meadow rice grass (Microlaena stipoides) ; Notodanthonia spp.; Vulpia spp. and soft brome (Bromus mollis) ) bwt only sweet vernal (8\%) and Yorkshire fog $(4 \%)$ made any appreciable contribution to total dry matter production and this was on the south aspect in autumn.

The total legume content on each 'aspect was similar in winter, spring and summer, reaching a peak in spring, but was much higher on the south (16\%) than the north (3\%) in 'autumn. There was usually less white clover (Trifolium repens) on the north than on the south but it was supplemented in winter and spring with subterranean clover (Trifolium subterrqneum). This was virtually absent from the south aspect. Similarly Lotus spp. added to north aspeot production in summer (8\%) but were barely noticeable in the south pasture at that time $(2 \%)$.

Pasture composition in winter reflected the autumn weather conditions and in particular the (timing of reliable autumn rain. When rain was delayed until late autumn (mid-April in 1971 and. 1973) there was more paspalum but less browntop, ryegrass, and subterranean clover in the sward on the north aspect in winter than when these seedlings were able to become well established before winter as in 1972 (early March rain). On the south aspect the total legume content, and particularly white clover, was lower after a dry autumn.

\section{PAsture Production}

The overall effect of higher soil moisture levels on the south aspect and warmer temperatures on the norbh was, along with induced differences in pasture composition, to 'stimulate about $10 \%$ more total pasture 'production from the north slopes than from the south (Fig. 4). The difference was mainly due to better growth on the north in winter and early spring (June to September) although in 1972 as :a result of early autumn rain (March) and a relatively cold winter the aspect difference was significant for six months from May to October. There was little difference between aspects at other times of the year although in December and January fastest pasture growth was measured on south slopes. However, in only one of three years was this difference significant.

Total pasture production tended to fall as land slope increased. This effect was greatest in spring but recorded at all times of the year except winter and although consistently significant on the south aspect was less frequently so on the north. However, 


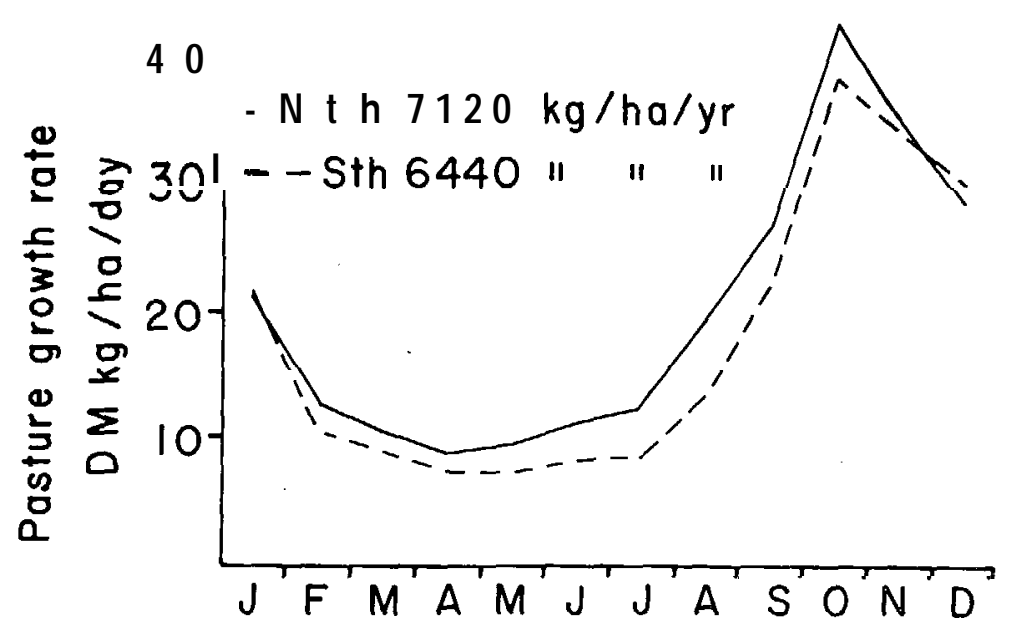

FIG. 4: Pasture dry matter production rate $(\mathrm{kg} / \mathrm{ha} /$ day $)$ at $30^{\circ}$ slope.

there was no real difference between aspects in the relationship and overall combined data showed that slope accounted for $22 \%$ of the variability in "pasture growth rate $(r=-0.47 \% *$ C.V. $=18 \%)$. With each degree increase in slope pasture production decreased by $109 \pm 26 \mathrm{~kg} \mathrm{DM} / \mathrm{ha} / \mathrm{yr}$. On the other hand, in winter and early spring pasture growth from the noath aspect tended to be greatest from the steepest slopes.

\section{DISCUSSION AND CONCLUSIONS}

In spite of the large temperature difference between aspects in winter, pasture growth on the north was not much greater than on the south. Similarly in summer and autumn the difference was maintained in spite of the very warm and dry conditions on the north aspect. This rather inflexible response in pasture growth rate on the north aspect to the changes in environment was a reflection of the greater adjustment in species composition 'during the year. Therefore, while paspalum helped maintain production from the north aspect in summer and autumn, the associated weak ryegrass content limited subsequent winter growth. The value of paspalum in summer and autumn must therefore be considered in relation to its effect in limiting greater winter production from the north aspect. 
The topsoil moisture level on the north aspect in late summer and early autumn was below wilting point and so pasture growth, paspelum in particular, was obviously sustained by subsoil moisture during this time. The depth of root penetration by different species was not measured but it is possible that 'aspects differed considerably in this respect. During autumn the soil moisture level on the north slopes was lower and tended to be replenished more slowly than the south. Consequently autumn rain took 2 to 3 weeks longer to germinate seeds and stimulate - general growth on north slopes. Early, reliable, 'autumn rain is therefore necessary if seedlings and legumes in particular are to become well established on both aspects before winter. Early autumn rain (March onwards) in 1972 encouraged more subterranean clover on the north and more white clover on the south aspects in the subsequent winter and spring than when it was delayed a further 4 to 6 weeks as in 1971 and 1973.

Although it is beyond the scope of this paper to suggest how to control the onset of autumn rain, it may be possible to note its effect in relation to pasture management in winter and early spring.

The relatively warm winter temperatures on north slopes indicate that potential growth could he much better than at present and may be stimulated considerably by nitrogen fertilizer. Even in years when the clover content was relatively high as a result of good establishment before winter, the benefit of added nitrogen should still be considerable. However, it is likely that most value would be obtained after a dry autumn. It is essential, however, that before any nitrogen fertilizer is used the phosphate level in the soil is sufficient to support and encourage ryegrass at the expense of less productive grasses such as browntop. Evidence collected during this trial suggests a general improvement in soil phosphate level and an associated decrease in the browntop content of the pasture. The relatively acid soil conditions, however, may be limiting pasture growth, clovers in particular, as has been illustrated by a response to lime on this soil (unpublished data). It is possible, then, that the environmental effects described may be buffered somewhat by growth limitations due to low soil $\mathrm{pH}$.

The effect of slope accounts for only $22 \%$ of the variability in pasture growth rate and is therefore difficult to relate to any single factor since several most likely combine to produce this effect. Change in slope had no detectable effect on topsoil (0 to $7.5 \mathrm{~cm}$ ) chemical fertility or 'bulk density, and therefore the soil 
water retentive ability (Archer and Smith, 1972), and so change in pasture growth rate was most likely related to such other Factors as temperature or species changes with slope. Additional grass temperature records and 'analysis of pasture species results showed both these factors to be at times also affected by slope and to explain 'some of its effect on pasture growth rate.

However, it is obvious that slope-related factors influencing growth were in the minority and that other variation's in microclimate, soil fertility and pasture utilization by stock imposed the greatest combined effect on production within the bill pasture.

\section{ACKNOWLEDGEMENTS}

Technical assistance from L. D. Bell, K. M. Murray, K. J. Prangley and Mrs D. M. Bellamy; herbage dissection analysis by Mrs C. Charlton and Mrs K. Fitzgerald; preparation of diagrams by the Ruakura Art Department; statistical analysis by D. Duganzich and staff, and (advice on instrumentation by P. F. Noble are greatly 'appreciated.

\section{REFERENCES}

Archer, J. A.; Smith, P. D., 1972: I. Soil Sci., 23: 475-80.

During, C.; Radcliffe, J. E., 1962: Trans. int. Soil Sci. Soc.: 685-90.

Gillingham, A. G.; During, c., 1973: N.Z. Il exp. Agric., 1: 227-32.

McCloud, D. E.; Bula, R. J.; Shaw, R. H., 1964: Adv. Agron., 16: l-58.

Rumball, P. J.; Esler, A. E., 1968: N.Z. Jl agric. Res., 11: 575-88. 